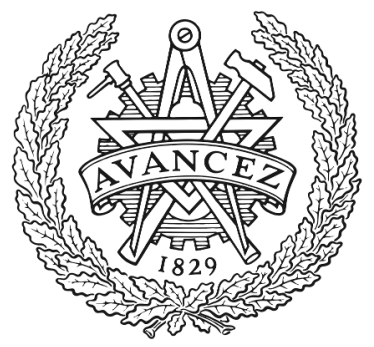

CHALMERS

UNIVERSITY OF TECHNOLOGY

\title{
Multifunctional land-use practices in Africa
}

Downloaded from: https://research.chalmers.se, 2023-04-26 12:58 UTC

Citation for the original published paper (version of record):

Simelton, E., Ostwald, M., Osiru, M. (2019). Multifunctional land-use practices in Africa.

Multifunctional Land Uses in Africa Sustainable Food Security Solutions

N.B. When citing this work, cite the original published paper. 


\title{
8 Multifunctional land-use practices in Africa
}

\section{What else do we need to do?}

\author{
Elisabeth Simelton, Madelene Ostwald and \\ Moses Osiru
}

\section{Key evidence of multifunctionality from the success stories: the 'what?'}

Recalling that multifunctional land use aims to produce more than one product or service, we ask: what lessons emerge from the six case studies? Let us look for a moment at the services and products produced and how farmers turned scarcities into resources.

\section{Raising fish where there is no water}

Two of the practices focus on services where water is central. Integrated watershed management is a landscape practice for better managing scarce or abundant water resources to meet several goals, such as reduced soil erosion and an increase in biomass in general (Teka Chapter 6). By reallocating water, more vegetation is sustained, and this may gradually alter the microclimate in the catchment to support a greater diversity of crops and trees, or increased crop yields. Fish farming in semi-arid environments is a realistic possibility. As technologies for recycling water advance and become affordable, it becomes a matter of selecting the appropriate fish species, identifying additional feed, and integrating with aquatic plants, fruit plants or trees, and shade-providing structures with hen houses (Matolla Chapter 5).

\section{Recovering poor soils}

Nutrient-poor soils are commonly identified as a limiting factor for African agriculture. As a collective term, climate-smart agriculture covers many kinds of practices (FAO 2013). The climate-smart agriculture examples presented here tackle multiple issues related to restoring soil carbon and soil fertility by incorporating residues and reducing tillage (Shomkegh Chapter 2). Parkland systems with scattered trees on grazing lands or on croplands produce a wide range of functions, from products like fodder, nuts, fruits or bark, to services such as improved water infiltration, shade, and carbon sequestration (Sanou Chapter 3). The shea parkland demonstrates soil-water 
interaction benefits between trees and associated crops. Both the cassava and the maize-based practices show that conventional staple crops such as maize and cassava, which are common in monocultures, can provide multiple benefits in diversified systems - without yield or income decline (Onoja Chapter 4; Adewopo Chapter 7). Furthermore, the integrated watershed management practice brought back groundwater tables and biomass to the landscapes (Teka Chapter 6), which has been a challenge in semi-arid landscapes where water deficits are common (Ilstedt et al. 2016; Nyberg et al. 2015).

\section{Win-wins and triple-wins: adaptation and mitigation co-benefits}

Contributions to climate change mitigation are often said not to motivate farmers to change practices and that mitigation should not be placed as an additional burden imposed on poor smallholder farmers, whose per-capita contributions to greenhouse gas emissions are miniscule. Many farming practices reported in this book represent adaptation to climate variability while contributing to increased carbon stocks in soils and vegetation (insitu mitigation benefits). However, the cassava and maize cases (Onoja Chapter 4; Adewopo Chapter 7) also reveal leakage issues of agricultural expansion leading to deforestation and forest degradation elsewhere (exsitu mitigation losses through emissions). In the Land Use, Land-Use Change and Forestry sector, this is one of the most contested challenges for greenhouse gas inventories. Leakage points to the importance of going beyond the fields to take a holistic view of the entire landscape with nested land uses, policy impacts at the national and international scale, and a comprehensive review of driving factors, including subsistence needs, markets, policy, and institutional factors (Duguma et al. 2019; Ostwald and Henders 2014). Frameworks that explore 'win-win' interactions between adaptation and mitigation and 'triple-wins' when development outcomes are added (Suckall et al. 2015) can guide more holistic, sustainable and hopefully long-lasting trade-off assessments. These 'win-win' interactions may not be anticipated by farmers and agriculture planners when focusing on one particular crop, practice or land use. Participatory land-use and emission scenarios can be used to simulate environmental and economic trade-offs, such as those between traditional agroforestry systems and oil palm development, to assess the policy and investment options that may enable sustainable land use (Mulia et al. 2013).

\section{Land scarcity, a challenge and opportunity for multifunctional agriculture}

While the term 'peri-urban agriculture' describes the location of the practice, the practice itself and its products and 'services', may vary (Onoja Chapter 4). The case study revealed that land scarcity and demand were 


\section{Elisabeth Simelton et al.}

the key factors driving the diversification of cassava-based systems. However, the role of peri-urban agriculture as a buffer of income and food for the poor should not be underestimated (Ferreira et al. 2018). With regard to land scarcity and fragmentation, the two climate-smart agriculture practices orchards and zero tillage provided an important insight, namely that smaller fields may be more cost-effective than larger ones (Shomkegh Chapter 2).

\section{Equality benefits livelihoods}

Several chapters highlight the differences between women's and men's opportunities to benefit and earn their livelihoods from agriculture (Onoja Chapter 4) and to participate in market-value chains. Examples show that women's exclusion from income-generating activities also affects other family members. The fish farming chapter illustrates how women organized themselves in groups to be stronger in market negotiations (Matolla Chapter 5). Several chapters (Shomkegh Chapter 2; Sanou Chapter 3; Teka Chapter 6) show, in various ways, that when women get involved and are able to convert 'inefficient' labour time into productive activities (with, for instance, shorter distances to water and markets) they make long-term investments. Further, the examples show that the additional incomes generated from multifunctional land uses were spent on paying back loans, on children's education, and on improved diets.

The six chapters confirm that food and ecosystem functions can be jointly produced. The multifunctionalities reported here often arose from adaptations to changes in the input supply, markets and demand, or in the natural environment. The cases contribute more diverse pictures than the conventional one of monoculture being the solution to 'feeding Africa'. Here, we emphasize that we reviewed only six cases on a vast continent that is home to countless types of land-use practices.

\section{Processes that bring about change: the 'how?'}

The chapters demonstrate multiple processes behind the transitions to more multifunctional land uses. Already in 2003 (AU 2004), African leaders had recognized that stagnant yields, poverty and food insecurity continued to hamper development throughout the continent. Through the Maputo Declaration on Agriculture and Food Security, African governments committed to allocate 10 per cent of their budgets to agriculture and rural development. This was coordinated regionally through the Comprehensive African Agricultural Development Plan (CAADP) and at national level through national agricultural investment plans aligned to CAADP goals. Then years later, a review of CAADP performance highlighted the need to set clear targets for driving agricultural development on the continent, resulting in the Malabo Declaration in 2014. They set targets 
such as ending hunger by 2025, halving poverty, enhancing resilience to climate change, and boosting intra-African agricultural trade. (Each country's progress on the targets can be tracked at: www.nepad.org/caadp.) International agreements like the Malabo Declaration are important mechanisms to attract investments from, for instance, the Green Climate Fund, the Global Environmental Facility, and the Bonn Challenge, to promote multifunctional practices. They provide mechanisms to ensure that knowledge, such as that highlighting benefits of multifunctional land use, can be used to support policy making at the national level.

Different contexts brought about the multifunctional land-use cases described in this book:

- Research and government projects and interventions as enablers. The cases with integrated watershed management and maize-based systems were driven through via government-led investments (Teka Chapter 6; Adewopo Chapter 7). This can result in scaling of interventions and meeting commitments, such as the Sustainable Development Goals and Nationally Determined Contributions, among others. While the concept of climate-smart agriculture (Shomkegh Chapter 2) at first was driven by the United Nations and members of academia, it has been advocated for and implemented through multiple stakeholder groups with guidelines in, for instance, Tanzania, Ethiopia, and Zimbabwe, and incorporated in national framework programmes, in, for example, Tanzania, Uganda, Namibia, and Kenya (Rosenstock et al. 2018).

- Community action groups and advocates of practices. 'Traditional' land uses are considered low-hanging fruit for development initiatives since support can be targeted to improve existing practices or plant improved varieties for well-tested crops and add value to existing products (Shomkegh Chapter 2; Sanou Chapter 3). This makes adoption of new practices smoother, as farmers have often already identified the problem and perhaps also the solution; and they see direct benefits of interventions (Kiptot and Franzel 2015).

- Farmer entrepreneurs as role models who can drive changes. The two fish farm examples show two farmers, one with more and one with fewer resources, who reached a point where they decided to take a risk and exit their comfort zones (Matolla Chapter 5). Both these farmers reached success in their risk-taking strategies. How many farmers have taken similar risks and failed, we do not know.

- Multifunctional land use resulting from unplanned responses to changed conditions. Earning livelihoods from staple food crops, like peri-urban cassava-based systems (Onoja Chapter 4), can be a challenge if land becomes more fragmented, land rents increase, land-use changes require investments or productivity is no longer maintained by simply adding more inputs. These conditions are in continuous change and must be monitored so that farmers and other decision-makers can 
take timely action. One such change due to reduced land resources and climate change is seen in West Pokot, Kenya where pastoralists have become more sedentary over the past decades. In this process the landscape has been transformed by the establishment of enclosures made from living trees and thorny bushes, which has increased the overall biomass in the area (Nyberg et al. 2015). The aim with the enclosures is to separate crops from animals. Once the crops are harvested the animals are fed on the residues (Figure 8.1).

\section{Capitalizing on benefits of multifunctional land use and research-informed policies is key}

Basin-scale integrated water management combined with on-farm units for water-use efficiency has the potential for maintaining surplus water, which

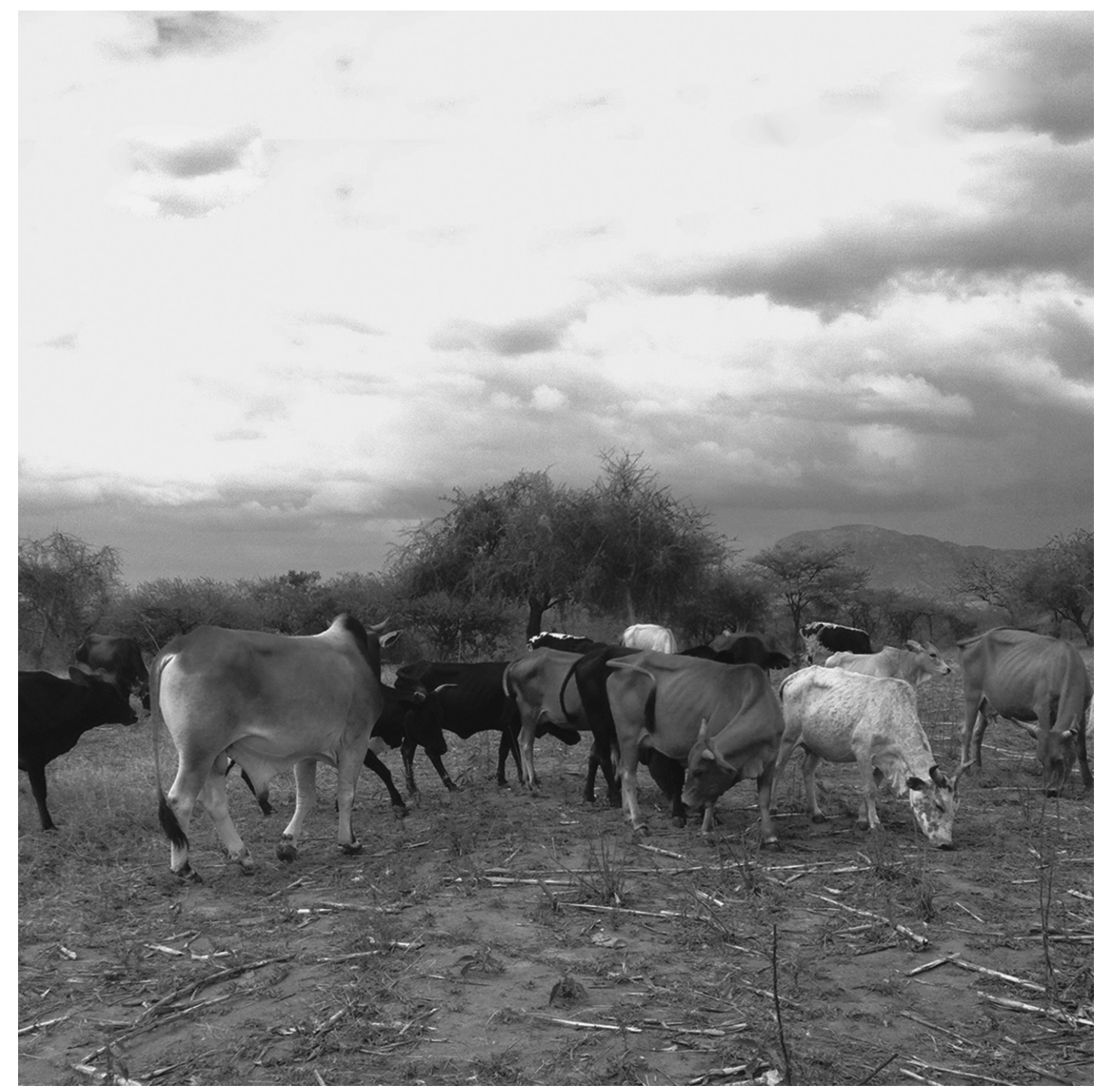

Figure 8.1 Animal grazing inside enclosure after harvest. West Pokot, Kenya. Photo credit: Ostwald 2013. 
is of relevance as governments will be expected to continue to invest in large-scale water management interventions and policies (Rockström et al. 2010). Informed policy processes will include identifying risks, developing and testing new animal breeds, plant varieties and agronomical practices. An informed policy process will also need to document socioeconomic and environmental benefits and implications of larger-scale adoption. One such example is within the international climate policy regime and its Paris Agreement, where estimates of avoided loss and damage are most likely to be included.

\section{Tenure is a policy area that requires attention}

Governments need to pursue tenure-related issues where these restrict multifunctional land uses and land use at large. Typical situations arise when the land user is not the land-owner, and when land leases are too short to motivate long-term investments, such as permanent tree stands. Further, customary rules may, for example, forbid people of a certain gender, tribe, or economic group to use the land or be associated with particular crops or parts of crops (Kiptot and Franzel 2012; Kiptot et al. 2014). As a step towards resolving some of the issues associated with insecure tenure and customary law, approximately 100 countries have ratified voluntary guidelines for tenure (FAO 2012).

\section{There is a fundamental need to understand farmers and risks}

We wish to challenge common statements like 'farmers are risk-averse', 'men take more risks than women', and 'younger people take more risks than older'. What defines their comfort zone will vary from case to case. First, investing your savings in a business is different from mortgaging the land your home is on to support that business idea. Second, asymmetric information creates power imbalances, which are unlikely to benefit smallholder farmers, particularly if they are women. Relatedly, when norms exclude some groups from business arenas, the time and risks involved to first break the norms and enter those arenas (if this is even possible) are very different to those experienced by actors already on those arenas (Nyasimi and Huyer 2017). Third, farmers and land users live with risks and are on constant standby to make rapid adjustments in response to weather situations. Farmers' economic investment capacity must be seen in relation to natural disaster risks and exposures, which, in marginal and resource-poor areas, may already have depleted assets and reduced buffers for dealing with further uncertainties, risks, and stresses (Demeke et al. 2016). Hence, before changing a complete farming system or investing in high technology systems, it makes sense to take small steps, experiment and assess the results. The fish farming chapter (Matolla Chapter 5) illustrates the struggles and risks common to business development. On the 
other hand, the examples also show that diversification can become a safety net when larger investments are at stake.

\section{Planned and unplanned actions can progress in similar ways}

The lessons from the case studies show that smallholder farmers approached their innovations in different ways and that both planned and unplanned actions were shown to result in progress. We highlight four approaches with applicability and relevance regardless of location.

\section{Small triggers that result in movement}

Training can be enough to enhance both economic and environmental benefits, as seen with capacity development for women in shea processing and business skills (Sanou Chapter 3). This reminds us that smaller grants and seed funds can trigger important steps towards reaching national targets and stimulate private co-investment, including start-ups and incubator opportunities. The non-governmental sector can also achieve scale by working directly with interest groups, farmer associations and rural resource centres.

\section{Practices can be gender neutral}

Chapters by Shomkegh (Chapter 2) and Matolla (Chapter 5) show that new land-use practices can be gender neutral, and the chapter by Sanou (Chapter 3) shows that women can be empowered by targeting their traditional practices and elevating their skills in the market-value chain. By providing equal training opportunities or introducing new practices as gender neutral, each new practice is an opportunity for men and women to do things differently and avoid cementing gender roles.

\section{Multifunctional components and practices can be shifted}

One solution is to introduce a higher-value crop so that the staple shifts to being the secondary component, as in the fruit orchards in Nigeria (Shomkegh Chapter 2). Increasing the soil organic matter can enhance crop nutrient uptake in nutrient-poor soils (Aworh 2015). Most staple crops lend themselves to intercropping with legumes; improving such practices can reduce the need for fertilizers and be affordable when horticulture or perennials are not an option. Farm ponds, community managed water schemes, and solar panels bring more control and ownership to farmers (Giordano et al. 2018).

To avoid overconsumption of chemical agro-inputs (Shomkegh Chapter 2; Onoja Chapter 4; Adewopo Chapter 7), governments may develop guidelines for good agricultural practices. These can include certain standards for 
food safety, well-being of producers and environmental impacts, where part of the strategy is for some types of producers to complete certification schemes, such as Good Agricultural Practice, Rainforest Alliance Certified ${ }^{\mathrm{TM}}$ or Verified Sourcing Areas. To implement practices and benefits, communities on the ground need investments in trained extension and advisory services. Governments could fund that kind of education through Green Climate Funds.

\section{E-farmers can build rural growth centres}

The fish farm example (Matolla Chapter 5) confirms that access to longerterm credit, which farmers often demand, can benefit farm development. Mobile phone services for agriculture are advanced in many parts of Africa and India. The fact that these were hardly mentioned in the cases studied is not because of their absence but rather a sign that they are already taken for granted. Information and communication technologies bring new hope for farmers to access credit and insurance, weather forecasts and market information, to share knowledge, monitor farm activities and receive advice. Services include, for example, iCow, which sends short messages about livestock and soil management (www.icow.co.ke), mpesa in Kenya which allows farmers to access and store money using simple handsets as well as pay for services (www.safaricom.co.ke/personal/m-pesa), and Esoko, which offers agricultural advice and payment services (www.esoko.com). These kinds of services are changing the way farmers can access information previously available only to certain groups and bypass middlemen to be in direct contact with customers and more readily respond to demand. Globally, digital solutions are expected to play fundamental roles in halving total greenhouse gas emissions in all sectors, including food, transport, agriculture and forestry, by reducing food waste, planting seedlings with drones, and more efficient use of resources in precision agriculture (Falk et al. 2018).

The chapters on shea (Sanou Chapter 3) and fish farms (Matolla Chapter 5) show how both local jobs and businesses can be created around a multifunctional enterprise. The community knowledge centres developed around the fish farms have functions similar to social enterprises. Rural resource centres have been established in Cameroon, Burkina Faso, the Democratic Republic of Congo, Mali and Nigeria since 2006 as a community-based extension service that complements the inadequate public agricultural extension service. The centres function as training and information hubs, with a tree nursery, demonstration plots, library and meeting room facilities. They are funded through a combination of organizational support, sales and service delivery, and volunteering. The work that these rural resource centres did in responding to local needs and training farmers on tree-based systems might otherwise not have happened, given that many public extension services are underfunded (Degrande et al. 2015; Takoutsing et al. 2014). 


\section{Elisabeth Simelton et al.}

The cases demonstrate that at certain scales, multifunctional land uses can survive without subsidies when farmers are part of the solution. When farmers and local leaders are engaged in project designs rather than passive recipients, their knowledge is respected and integrated into the solutions. Incorporating local knowledge helps in understanding how different types of land users understand and explain what happens in their environment, what matters to them, and their interactions with other groups about shared resources (Kmoch et al. 2018; Simelton and Dam 2014). For this reason, it is interesting to study top-down interventions, such as Ethiopia's watershed management programmes (Teka Chapter 6), which resemble those in China and Vietnam in the 1990s and 2000s (Bachewe et al. 2018). Here, large-scale interventions in extension and availability of inputs (especially financial), combined with farmers' contributions of labour-for-food, seem to have worked, in times when and places where economic development standards were quite similar. Planners will now need to avoid creating new problems when solving an environmental issue.

\section{Benefits of multifunctional land uses for Africa: the 'So what?'}

While many seem to agree that we need to increase yields and ensure diverse diets, research on food security seems to focus on either the quantity or the quality of food - and smallholder farmers are often forgotten either way (Ickowitz et al. 2019). In this book, we have tried to show a variety of agricultural practices that return more than the yields to smallholders' livelihoods and communities. Returning to Wiggering et al. (2006) in Simelton, Ostwald and Osiru (Chapter 1), we ask: knowing all these benefits, so what? Which of the values of multifunctional land use does the rest of society perceive to be important so that these environmental and social functions can be maintained?

\section{The costs of poverty and food insecurity}

Some of the case studies showed what happens when poor households increase their incomes. They invested in short- and long-term returns: improved diets and their children's education. While counting the number of poor is comparatively straightforward, estimating the cost of poverty is more complex. A study from the United States showed that the cost of child poverty is about 5.4 per cent of the gross domestic product and estimated that every dollar the country spent on reducing childhood poverty would save at least seven dollars (McLaughlin and Rank 2018). In developing countries, it turns out that the net food and agricultural exporters invested more in social protection programmes that benefitted the rural poor, than those with agricultural trade deficits and manufacturing trade surpluses (Desai and Rudra 2018). 
The public costs for food insecurity, such as those of the civil unrest and recovery of people who fell into poverty with the food price inflation 2007-2008 (Berazneva and Lee 2013; Simelton 2010, 2011; Veninga and Ihle 2018), are not explicit in the frameworks of Garibaldi et al. (2017) and Vereijken (2003). These may depend on European-centred frameworks that take institutional roles and food security for granted and instead aim to embed natural, cultural and recreational values in schemes for payments for ecosystem services. In some cases, the roles for multifunctional agriculture and smallholders are clearly stressed, such as Niger's socioeconomic development plan 2012-2015 (FAO 2015). Others argue that global food prices are linked to the food security of urban low-income net food buyers. In such contexts, commercial medium-scale farms are expected to contribute to food security by job creation and (rural) wages (Meyfroidt 2018). Furthermore, the benefits of agricultural exports are less clear when it comes to foreign acquisition of agriculture land. A global estimate of large-scale land acquisition for commercial agriculture shows that although the relevant area could feed 300 to 500 million people through intensification, the food is exported from countries with a high prevalence of poverty and malnourishment, disrupting their sources of livelihoods (Rulli and D’Odorico 2014).

\section{The yield gap}

Rainfed agriculture continues to play an important role for many farming systems, while yields in many countries are less than 30-40 per cent of their potential yields (Rockström et al. 2010). Feeding the growing population on less farmland will require a transformation of the whole agrifood system as we know it. The value chain starts with improved stress-tolerant seeds and a combination of diverse farming systems that are adapted to new climatic situations. Some of the potentially climate resilient crops suitable for Africa are generally under-researched, such as pigeon pea, cowpea, sweet potato, lentils, and chickpeas (Manners and van Etten 2018). New business opportunities may arise from taking advantage of underutilized food crops, so-called orphan crops, for enhanced nutritional diets (Aworh 2015, see also http://africanorphancrops.org/), and exploring the abundance of wild foods that can be domesticated (Bvenura and Sivakumar 2017). Integrated watershed management combined with climate-smart agriculture and fish farming (Shomkegh Chapter 2; Matolla Chapter 5; Teka Chapter 6) interventions are promising examples for the potential reduction of yield gaps. The example from the Tigray region of Ethiopia estimated investment costs for water harvesting bunds in the three watersheds to be between US\$29 and 87 per hectare, with annual maintenance costs of US\$1.7 and 6.1 per hectare (Teka Chapter 6). In industrial production, such expenses are added to the consumer price. Here, weighted against gains in food 
security, people's living standards and re-greening of landscapes - what is a 'fair price'? How should a 'fair price' be defined?

\section{Local and global values of agriculture ecosystems}

Who needs to pay greater attention to intensification and expansion of agriculture? The literature reviewed by Garibaldi et al. (2017) compared 154 conventional and 13 alternative practices, such as sustainable intensification, organic, diversification, ecological intensification and agroecological farming systems. Interestingly, 61 per cent of the comparisons showed greater crop yield for alternative rather than conventional practices, whereas about 20 per cent showed the opposite trend and another 20 per cent showed no differences. Similarly, two-thirds of the comparisons achieved greater farm profitability for alternative practices, while 11 per cent found the opposite trend, and 23 per cent showed no differences. Few of the studies provided quantitative data on both crop yield and socioeconomic indicators, such as well-being; hence, little evidence was documented on the multifunctionality of alternative practices. Furthermore, when agriculture intensification involves conversion of forests and grassland to agriculture, this poses threats to natural resources and habitats. National and subnational decision-makers can develop policies that reduce land conversions while building up habitat quality on existing agricultural land. Policies can also be designed to give farmers incentives to invest in conservation agriculture and agrobiodiversity, including by offering tenure security and access to credit and efficient markets (Perrings and Halkos 2015). Furthermore, countries can prevent agriculture-driven deforestation, with or without large-scale land acquisitions, by including land management principles, for example, in their REDD+ strategies (Carter et al. 2017). The 'Economics of Ecosystems and Biodiversity AgriFood' initiative is a multidisciplinary platform that provides guidance for more comprehensive evaluations of eco-agri-food systems (http://teebweb.org/agrifood/).

\section{Resilience to environmental degradation and climate change impacts}

Integration of more trees in agriculture and farming practices that prevent land degradation can enhance carbon sinks (Zomer et al. 2016). A suitability mapping of shea trees shows a potential distribution on 340 million hectares across 23 countries (Naughton et al. 2015). The mapping study estimated that this corresponds to 1.8 billion trees and would involve 18 million women collectors. As technology improves, remote-sensing tools will enable us to count individual trees. Using remote sensing, Bastin et al. (2017) identified 467 million hectares of dryland forests that had not been reported previously. Further, they estimated that 1,327 million hectares of drylands had more than 10 per cent tree cover in 2015, such as the shea 
parklands. Such remote-sensing methods can offer affordable and objective solutions for monitoring tree plantation efforts and estimating their benefits, which are often among the most difficult parts of reporting on commitments to the United Nations Framework Convention on Climate Change and carbon financing projects (Rosenstock et al. 2018).

\section{The cost of adapting or not adapting agriculture to climate change}

Estimating and comparing the costs and benefits of different adaptation options, including not adapting, is a complex matter that depends on the type of calculated and emerging risks and the projected frequency and intensity of those risks (Klein et al. 2014). It also involves consideration of the ethically acceptable risks and adaptation opportunities among different groups of individuals (Niang et al. 2014). Estimates suggest that the cost of not adapting farming systems to climate change will be about 5 per cent of the gross national product by 2030, while estimates of adaptation costs range from two US dollars per person for a national climate change strategy in Rwanda to six US dollars per person for protecting pastoralist and livestock systems in Tanzania. More importantly, delayed action was estimated to cost ten times more by 2030 (IIED 2011). It is becoming more evident that public sources will become insufficient and that private finance is needed. Climate finance from public sources is typically given to profitable mitigation interventions, for example renewable energy, rather than to adaptation activities in the land-use sector (Oliver et al. 2018). In 2017, private climate finance at global level was reported at 249 billion US dollars. Of this amount, 238 billion was for renewable energy (Oliver et al. 2018). There are opportunities to include multifunctional agricultural land as part of green infrastructure and ecosystem-based adaptation strategies in adaptation funds or payment for ecosystem services schemes, where consumers recognize environmental services achieved by farmers. The buffering roles of agriculture during environmental and economic crises must be reflected in budget allocations for disaster risk and climate adaptation (FAO 2018).

\section{The role of science in promoting sustainable land-use practices and food security: 'what else do we need to know?'}

The examples from this book show that the proper quantification and valuation of multiple products and services from land has room for scientific and practical improvements. Documenting the multiple functions that multifunctional land uses have will include their resilience to external stress, the value of replacing external inputs with ecosystem services, and complementarity or positive interactions. Garibaldi et al. (2017) suggested an evidence framework that draws on social, human, cultural, natural, financial, and economic assets (Table 8.1). Arguing that food security will 


\section{Elisabeth Simelton et al.}

Table 8.1 Example of indicators for assessing the multifunctionality of farming practices

$\begin{array}{lll}\text { Rural functions } & \text { Typical performance } & \text { Our suggested indicators } \\ \text { Vereijken 2003 } & \text { indicators } & \text { Research questions, partly drawn } \\ & \text { Garibaldi et al. 2017 } & \begin{array}{l}\text { from this book, to compare } \\ \text { 'conventional' and multifunctional } \\ \end{array} \\ & \text { land use }\end{array}$

Health and Encourages non-farmed wellness species diversity

Nature and landscape

Environment and climate

Production
Encourages spatial heterogeneity

Explicit focus on traditional knowledge

Use of synthetic inputs vs use of organic inputs

Exploits ecosystem services
- Does starting the practice require a particular 'farmer characteristic': are food security, start-up capital/ time, certain social/human assets prerequisites for the practice?

- How does the land use contribute to household/local/national food security?

- Does the land use cement existing social or gender inequalities? Does the practice help free up unpaid time or reduce physically demanding workloads or exposure to dangerous substances?

- What biodiversity values are enhanced by the land use?

- Does the land use help beautify the landscape or contribute to agro-tourism?

- Is the research design informed by various local groups' knowledge and needs from the beginning?

- What are the values of replacing external inputs with ecosystem services (for instance, exchanging pesticides for biological pest control, inorganic fertilisers for compost), or complementarity and positive interactions?

- To what extent are herbicides solely used to save labour costs for weeding?

- Does the land use reduce sensitivity to adverse climatic impacts? Does the land use contribute to sequestering carbon or reducing greenhouse gas emission, directly or indirectly (through its value chain, such as reducing transports)?

- How is land-use efficiency evaluated? What are the individual and combined differences in yield and income? 
Table 8.1 Continued

\begin{tabular}{lll}
\hline Rural functions & Typical performance & Our suggested indicators \\
Vereijken 2003 & indicators & Research questions, partly drawn \\
& Garibaldi et al. 2017 & from this book, to compare \\
& & 'conventional' and multifunctional \\
& land use
\end{tabular}

Wealth and Highly labour dependent income

- Are new jobs created? Do they develop new specialists or service providers, such as processing, information and communication technologies, intermediaries, transport?

- Do multifunctional farming systems avoid market saturation and a rural economy dependent on few products?

NA Plans for resilience

- What are the costs, benefits, and

Exploits processes at multiple temporal and spatial scales potential risks associated with the land use? How are they balanced? How do benefits spill over to the wider community and natural environment?

- Who is looking for return on investment (public or private, grants or loans) and over what period?

Impacts at scale

- Social and institutional buy-in in top-down interventions versus the role of markets in driving multifunctional practices.

- What policies are in place that enable or discourage multifunctional practices? What policymakers and other actors are involved/missing as stakeholders in the process?

- Are rural and urban food-security links strengthened?

Sources: Adapted from Vereijken (2003) and Garibaldi et al. (2017).

not be solved by increasing crop yields alone, they take agricultural sustainability to depend on government and civil society actions, including rural communities, researchers and technicians. Here, we have modified the frameworks of Vereijken (2003) and Garibaldi et al. (2017) to make explicit institutional functions and food security (meaning quantitative and qualitative stability of nutrients) and stress the impacts at scale. Similar classifications have been adapted for modelling tools, such as the Common 
International Classification of Ecosystem Services (https://cices.eu/ supporting-functions/; Potschin and Haines-Young 2011), and developed into typologies for mapping flows of ecosystem functions (Pagella and Sinclair 2014).

To get a sense of the role of science in African agriculture, we conducted a small anonymous survey among different scientific and agricultural networks globally with the aim of giving us an indication of relevant issues. Without any goal of methodological soundness or genuine analysis, this provides a hint of some of the debates that exist today.

The first question in the survey was: 'What is the major critical research area that needs to be in focus to sustainably strengthen African agriculture?' Two major research needs appeared: (i) adaptation to change, (ii) climatic and entrepreneurial and market-related knowledge. In the former case, respondents mentioned modalities of agricultural management in a changing climate and, more explicitly, in the event of shocks. The source of information given to smallholder farmers was stated as problematic and fragmented or too homogenous. On the same note, there is a lack of knowledge on the environmental impacts of different types of production systems. Respondents also highlighted the need for more knowhow on the value chains of agricultural products and on how farmers can enter the market and become entrepreneurial actors in the African agriculture sector. Based on our own non-scientific interpretation, the narratives that are being retold regarding African agriculture are hampering the development of the same. This dominating, repetitive and unfavourable narrative is also the basic idea that has been driving this book project.

The second question we asked was about the 'most damaging myths about African agriculture'. Some respondents stated that 'farming equals poverty', 'African agriculture is one homogenous system', and 'soil degradation is irreversible' as examples of such myths. The dominating myth damaging African agriculture, however, relates to 'the irrational African farmer', 'the inefficient production', and 'that farmers are not forward-looking or market-oriented'. Although it is possible to find scientific evidence to support each of these statements, the myths are created when one repeated narrative points to an immutable nature of African agriculture. Rather than fuelling damaging myths, the role of science is to contribute more diverse realities and bring constructive evidence of ongoing agriculture developments in Africa that are taking farmers, consumers and leaders on long-term sustainable trajectories.

This brings us to the third question: 'How is the myth, true or untrue, hampering sustainable development of agriculture in Africa?' The answers from our colleagues pinpointed this drawback by exemplifying how these narratives or myths drive general policy processes in Africa. For example, efforts that focus on developing new agricultural technologies at a fairly scientific and technocratic level rather than on the adoption of technologies that already exist, a process strongly driven by how funding streams flow 
into agricultural research and development. One approach, with lower investment cost and faster adoption, could be to build on existing and well-functioning technologies that can reduce those risks. These practices are often sporadic and contextual, and therefore not well known, well documented or well presented. Another example is the impact that unfavourable myths have on youth in agriculture, since 'farming is portrayed as a non-prosperous or bad career choice', making it an unattractive option for young people, which on the other hand is not unique to Africa. The remedy to this downward spiral is to showcase that money can be earned in agriculture and that it can offer a good livelihood. Enhancing the appeal of agriculture requires investments in infrastructure, including roads, markets, rural services, and irrigation, and clear incentives for adopting new technologies and becoming more involved in post-harvest processing stages of the value chain. 'Abandoning the one-size-fits-all solution within extension and policy' and 'focusing on enhancing agricultural and contextspecific research' were suggested as steps on the path towards more prosperous agricultural progress.

Finally, we asked our colleagues to think of 2063, linking to the Africa Union Agenda 2063 for the socioeconomic transformation within the African Union (AUC 2015). We asked them to 'state the biggest risks and strengths within African agriculture'. The three major risks they foresee are (i) impacts of climate change and associated water stress, (ii) the looming population increase, and (iii) land shortage. Three strengths were seen in (i) African youth who are expected to be better educated than today, (ii) the richness in natural resources, such as favourable growing climates and minerals, and (iii) diversity of products, production systems and market channels that hold great potential.

\section{Where do we go from here?}

Scientists have raised concerns over the promotion of single adaptation responses - such as crop insurance or new crop varieties - that increase the vulnerability to climate risks by disincentivizing practices that would lead to more positive outcomes over longer time scales. Vermeulen et al. (2018) reviewed case studies that met their criteria for transformational adaptation to climate change, including eight African agricultural systems. Among the successful transformational changes in Niger, was, not just giving farmers technical assistance, but also control over assets. The study concludes that governments and development partners could improve the effectiveness of outcomes by providing more comprehensive and long-term approaches to adaptation planning alongside financial and technical assistance, within a framework that rewards farms as multifunctional systems.

This involves a shift from the global to local levels, to understand and economically reward farms as multifunctional land-use systems that deliver food (health and nutrition), profits, jobs, environmental benefits and 
cultural value that goes beyond national food security. The role of governance is to ensure inclusive decision-making and distribution of outcomes. Adaptation processes need to be implicitly included within the Comprehensive Africa Agriculture Development Programme (CAADP), which is Africa's framework for agricultural transformation reinforced by the 2014 Malabo Declaration, the Science, Technology and Innovation Strategy for Africa 2024, commitments to the United Nations Framework Convention on Climate Change such as the global stocktake, Nationally Determined Contributions through the Green Climate Fund, and loans and grants from development banks. Technical and financial assistance for identifying adaptation options may include compensation for transformative changes, information, and knowledge systems that give farmers tools to forecast possible futures, and for monitoring systems that give early warning of agricultural systems being on the wrong track, away from long-term sustainability (Niang et al. 2014; Vermeulen et al. 2018). The importance of these issues needs to be highlighted in the curriculum for future leaders.

The six case studies presented in this book provide promising alternatives to the conventional view that global food security requires largescale monoculture production of staple crops. Research on multifunctional land use can help us better understand the interactions in these diverse socioecological systems.

Our cases have mainly concerned multifunctional practices that may be incremental adaptation responses to current risks; in particular, water, rainfall, and food and land security and shortages. Identifying various factors as aspects of past and current success does not mean they would enable near-term or long-term future sustainability; in general, there are temporal trade-offs between short- and long-term goals or spatial tradeoffs, for example between ending some land use now for the sake of setting aside land elsewhere.

We hope that this book will inspire, provoke reflection and action on enhanced multifunctional land use, and initiate more research.

\section{References}

[AU] African Union. 2004. The Comprehensive African Agricultural Development Program - CAADP. African Union. Addis Ababa, Ethiopia. www.nepad.org/ caadp.

[AUC] African Union Commission. 2015. Agenda 2063 The Africa We Want. 01 Background Note. African Union Commission. Addis Ababa. https://au.int/sites/ default/files/documents/33126-doc-01_background_note.pdf.

Aworh O. 2015. Promoting food security and enhancing Nigeria's small farmers' income through value-added processing of lesser-known and under-utilized indigenous fruits and vegetables. Food Research International 76(4):986-991.

Bachewe FN, Berhane G, Minten B, Taffesse AS. 2018. Agricultural Transformation in Africa? Assessing the Evidence in Ethiopia. World Development 105:286-298. 
Bastin J, Berrahmouni N, Grainger A, Maniatis D, Mollicone D, Moore R, Patriarca C, Picard N, Sparrow B, Abraham E et al. 2017. The extent of forest in dryland biomes. Science 356:635-638.

Berazneva J, Lee D. 2013. Explaining the African food riots of 2007-2008: An empirical analysis. Food Policy 39:28-39.

Bvenura C, Sivakumar D. 2017. The role of wild fruits and vegetables in delivering a balanced and healthy diet. Food Research International 99(1):15-30.

Carter S, Manceur A, Seppelt R, Hermans-Neumann K, Herold M, Verchot L. 2017. Large scale land acquisitions and REDD+: a synthesis of conflicts and opportunities. Environmental Research Letters 12(3):035010.

Degrande A, Tchoundjeu Z, Kwidja R, Fouepe G. 2015. Rural Resource Centres: a community approach to agricultural extension. Note 10. GFRAS Good Practice Notes for Extension and Advisory Services. Lindau, Switzerland. www.world agroforestry.org/downloads/Publications/PDFS/BR15624.pdf.

Demeke M, Kiermeier M, Sow M, Antonaci L. 2016. Agriculture and food insecurity risk management in Africa. Concepts, lessons learned and review guidelines. Food and Agriculture Organization of the United Nations. Rome. 92p. www.fao.org/3/a-i5936e.pdf.

Desai R, Rudra N. 2018. Trade, poverty, and social protection in developing countries. European Journal of Political Economy. doi.org/10.1016/j.ejpoleco.2018. 08.008 .

Duguma L, Atela J, Minang P, Ayana A, Gizachew B, Nzyoka J, Bernard F. 2019. Deforestation and forest degradation as an environmental behavior: unpacking realities shaping community actions. Land 8(2):26.

Falk J, Gaffney O, Bhowmik AK, Borgström-Hansson C, Pountney C, Lundén D, Pihl E, Malmodin J, Lenhart J, Jónás K et al. 2018. Exponential climate action roadmap future Earth. Sweden. 108p. https://exponentialroadmap.org/wp-content/ uploads/2018/09/Exponential-Climate-Action-Roadmap-September-2018.pdf.

[FAO] Food and Agriculture Organization of the United Nations. 2012. Voluntary Guidelines on the Responsible Governance of Tenure of Land, Fisheries and Forests in the Context of National Food Security. Food and Agriculture Organization of the United Nations. Rome. www.fao.org/docrep/016/i2801e/i2801e. pdf.

[FAO] Food and Agriculture Organization of the United Nations. 2013. Climatesmart Agriculture - Sourcebook. Food and Agriculture Organization of the United Nations. Rome. 570p. www.fao.org/3/i3325e/i3325e.pdf.

[FAO] Food and Agriculture Organization of the United Nations. 2015. Collaboration for Strengthening Resilience. Country Case Study Niger. Food and Agriculture Organization of the United Nations, International Fund for Agricultural Development, World Food Programme. Rome. 20p. https://documents. wfp.org/stellent/groups/public/documents/newsroom/wfp278361.pdf?_ $\mathrm{ga}=2.249800582 .1647555720 .1549691044-1411497054.1549691044$.

[FAO] Food and Agriculture Organization of the United Nations. 2018. 2017 The Impact of Disasters and Crises on Agriculture and Food Security. Food and Agriculture Organization of United Nations. Rome. 168p. www.fao.org/policysupport/policy-themes/disaster-risk-reduction-agriculture/en/.

Ferreira A, Guilherme R, Ferreira C, Oliveira M. 2018. Urban agriculture, a tool towards more resilient urban communities? Current Opinion in Environmental Science and Health 5:93-97. 


\section{Elisabeth Simelton et al.}

Garibaldi LA, Gemmill-Herren B, D’Annolfo R, Graeub B, Cunningham S, Breeze T. 2017. Farming Approaches for Greater Biodiversity, Livelihoods, and Food Security. Trends in Ecology \& Evolution 32(1):68-80. doi:10.1016/j.tree.2016.10.001.

Giordano M, Barron J, Unver O. 2018. Water scarcity and challenges for smallholder agriculture. In: Campanhola C, Pandey S (eds). Sustainable Food and Agriculture. An integrated approach. Academic Press. Cambridge, USA. https:// hdl.handle.net/10568/988597.

Ickowitz A, Powell B, Rowland D, Jones A, Sunderland T. 2019. Agricultural intensification, dietary diversity, and markets in the global food security narrative. Global Food Security 20:9-16.

[IIED] Institute for Environment and Development. 2011. Costing agriculture's adaptation to climate change. The International Institute for Environment and Development. London. 4p. http://pubs.iied.org/pdfs/17120IIED.pdf.

Ilstedt U, Bargués A, Tobella HRB, Bayala J, Verbeeten E, Nyberg G, Sanou J, Benegas L, Murdiyarso D, Laudon H, Sheil D, Malmer A. 2016. Intermediate tree cover can maximize groundwater recharge in the seasonally dry tropics. Nature Scientific Reports 6:21930.

Kiptot E, Franzel S. 2012. Gender and agroforestry in Africa: a review of women's participation. Agroforestry Systems 84(1):35-58.

Kiptot E, Franzel S. 2015. Farmer-to-farmer extension: opportunities for enhancing performance of volunteer farmer trainers in Kenya. Development in Practice 25(4):503-517.

Kiptot E, Franzel S, Degrande A. 2014. Gender, agroforestry and food security in Africa. Current Opinion in Environmental Sustainability 6:104-109.

Klein RJT, Midgley GF, Preston BL, Alam M, Berkhout FGH, Dow K, Shaw M. 2014. Adaptation opportunities, constraints, and limits. In: Field CB, Barros VR, Dokken DJ, Mach KJ, Mastrandrea MD, Bilir TE, Chatterjee M, Ebi KL, Estrada YO, Genova RC et al. Climate Change 2014: Impacts, Adaptation, and Vulnerability. Part A: Global and Sectoral Aspects. Contribution of Working Group II to the Fifth Assessment Report of the Intergovernmental Panel on Climate Change. Cambridge University Press, Cambridge, United Kingdom and New York, NY, USA. P 899-943.

Kmoch L, Pagella T, Palm M, Sinclair F. 2018. Using local agroecological knowledge in climate change adaptation: a study of tree-based options in Northern Morocco. Sustainability 10(10):3719.

Manners R, van Etten J. 2018. Are agricultural researchers working on the right crops to enable food and nutrition security under future climates? Global Environmental Change 53:182-194.

McLaughlin M, Rank M. 2018. Estimating the economic cost of childhood poverty in the United States. Social Work Research 42(2):73-83.

Meyfroidt P. 2018. Trade-offs between environment and livelihoods: bridging the global land use and food security discussions. Global Food Security 16:9-16.

Mulia RA, Widayati A, Suyanto S, Agung P, Zulkarnain M. 2013. Low carbon emission development strategies for Jambi, Indonesia: simulation and trade-off analysis using the FALLOW model. Mitigation and Adaptation Strategies for Global Change. doi:10.1007/s11027-013-9485-8.

Naughton C, Lovett P, Milhelcic J. 2015. Land suitability modeling of shea (Vitellaria paradoxa) distribution across sub-Saharan Africa. Applied Geography $58: 217-227$. 
Niang I, Ruppel O, Abdrabo M, Essel A, Lennard C, Padgham J, Urquhart P. 2014. Africa. In: Barros VR, Field CB, Dokken DJ, Mastrandrea MD, Mach KJ, Bilir TE, Chatterjee M, Ebi KL, Estrada YO, Genova RC et al. (eds) Climate Change 2014: Impacts, Adaptation, and Vulnerability. Part B: Regional Aspects. Contribution of Working Group II to the Fifth Assessment Report of the Intergovernmental Panel on Climate Change. Cambridge University Press, Cambridge, United Kingdom and New York NY. P 1199-1265.

Nyasimi M, Huyer S. 2017. Closing the gender gap in agriculture under climate change. Agriculture for Development 30:37-40.

Nyberg G, Knutsson P, Ostwald M, Oborn I, Wredle E, Otieno D, Mureithi S, Mwangi P, Said M, Jirström M et al. 2015. Enclosures in West Pokot, Kenya: transforming land, livestock and livelihoods in drylands. Pastoralism: Research, Policy and Practice 5:25.

Oliver P, Clark A, Meattle C. 2018. Global Climate Finance: An Updated View 2018 Climate Policy Initiative. https://climatepolicyinitiative.org/publication/ global-climate-finance-an-updated-view-2018/; https:/climatepolicyinitiative.org/ wp-content/uploads/2018/11/Global-Climate-Finance-An-Updated-View-2018. pdf.

Ostwald M, Henders S. 2014. Making two parallel land-use sector debates meet: carbon leakage and indirect land-use change. Land Use Policy 36:533-542.

Pagella T, Sinclair F. 2014. Development and use of a typology of mapping tools to assess their fitness for supporting management of ecosystem service provision. Landscape Ecology 29(3):383-399.

Perrings C, Halkos G. 2015. Agriculture and the threat to biodiversity in subSaharan Africa. Environmental Research Letters 10(9). doi:10.1088/1748-9326/ 10/9/095015.

Potschin M, Haines-Young R. 2011. Ecosystem services: Exploring a geographical perspective. Progress in Physical Geography 35(5): 575-594.Rockström J, Karlberg L, Wani S, Barron J, Hatibu N, Oweis T, Bruggeman A, Farahani J, Qiang Z. 2010. Managing water in rainfed agriculture - the need for a paradigm shift. Agricultural Water Management 97:543-550.

Rosenstock T, Wilkes A, Jallo C, Namoi N, Bulusu M, Suber M, Bernard F, Mboi D. 2018. Making trees count: measurement, reporting and verification of agroforestry under the UNFCCC. CGIAR Research Program on Climate Change, Agriculture and Food Security (CCAFS). Wageningen, the Netherlands. https:// hdl.handle.net/10568/98404.

Rulli M, D'Odorico P. 2014. Food appropriation through large scale land acquisitions. Environmental Research Letters 9:064030.

Simelton E. 2010. Don't we all want good weather and cheap food? In: Dodson J (ed.). Changing Climates, Earth Systems and Society. Springer. P 201-215.

Simelton E. 2011. Food self-sufficiency and natural hazards in China. Food Security $3: 35-52$.

Simelton E, Dam VB. 2014. Farmers in NE Viet Nam rank values of ecosystems from seven land uses. Ecosystem Services 9:133-138.

Suckall N, Stringer LC, Tompkins EL. 2015. Presenting triple-wins? Assessing projects that deliver adaptation, mitigation and development co-benefits in rural Sub-Saharan Africa. Ambio 44(1):34-41.

Takoutsing B, Tchoundjeu Z, Degrande A, Asaah E, Tsobeng A. 2014. Scaling-up sustainable land management practices through the concept of the rural resource 


\section{Elisabeth Simelton et al.}

centre: reconciling farmers' interests with research agendas. International Journal of Agricultural Extension Education 20(5):463-483.

Veninga W, Ihle R. 2018. Import vulnerability in the Middle East: effects of the Arab spring on Egyptian wheat trade. Food Security 10(1):183-194.

Vereijken P. 2003. Transition to multifunctional land use and agriculture. NJAS Wageningen Journal of Life Sciences 50(2):171-179.

Vermeulen S, Dinesh D, Howden S, Cramer L, Thornton P. 2018. Transformation in practice: a review of empirical cases of transformational adaptation in agriculture under climate change. Frontiers in Sustainable Food Systems. https://doi. org/10.3389/fsufs.2018.00065.

Wiggering H, Dalchow C, Glemnitz M, Helming K, Müller K, Schultz A, Stachow U, Zander P. 2006. Indicators for multifunctional land use - linking socioeconomic requirements with landscape potentials. Ecological Indicators $6(1): 238-249$.

Zomer R, Neufeldt H, Xu J, Ahrends A, Bossio D, Trabucco A, van Noordwijk M, Wang M. 2016. Global tree cover and biomass carbon on agricultural land: the contribution of agroforestry to global and national carbon budgets. Nature Scientific Reports 6. doi:10.1038/srep29987. 